\begin{tabular}{|l|l|l|l|}
\hline Eiszeitalter u. Gegenwart & 35 & $\begin{array}{c}23-32 \\
7 \mathrm{fig} .\end{array}$ & Hannover 1985 \\
\hline
\end{tabular}

\title{
Development and Evolution of Sedimentary Environments during the Holocene in the Western Coastal Plain of Belgium
}

\author{
Cecile BaEteman *)
}

\begin{abstract}
Shore features, morphodynamics, sedimentary environment, depression, erosion, sand, subsoil, Holocene, borehole sections, panel diagram.

Belgium (Western Coastal Plain)
\end{abstract}

A b s t r a c t : The interrelationship of the different depositional sedimentary environments in their areal distribution and through time has been investigated in a sandy area of the Western coastal plain of Belgium. The sandy area is used to be interpreted as the result of one single post-Roman erosive phenomenon. The study of the entire Holocene sequence and the three-dimensional view of it showed the existence of a depression in the pre-Holocene surface where initially a tidal flat came into being in which tidal channels developed. The erosive actions of these tidal channels however were restricted to different distinct places and depth.

\section{[Ausbildung und Entwicklung der Ablagerungsmilieus in der westlichen Küstenebene Belgiens im Verlauf des Holozän]}

$\mathrm{Ku} \mathrm{r} \mathrm{z} \mathrm{f} \mathrm{a} \mathrm{s} \mathrm{u} \mathrm{n} \mathrm{g}$ : In einem Gebiet sandiger Ablagerungen in der westlichen Küstenebene von Belgien wurden die räumlichen und zeitlichen Beziehungen verschiedener Ablagerungsmilieus zueinander untersucht. Das Sandgebiet wird gewöhnlich als Ergebnis eines einzigen poströmischen Erosionsereignisses angesehen. Die Untersuchung der gesamten Holozänabfolge und ihre räumliche Betrachtung ergaben jedoch eine Depression in der präholozänen Oberfläche, in der sich ursprünglich ein Watt entwickelte und sich dann Gezeitenrinnen herausbildeten. Die Erosionswirkung dieser Gezeitenrinnen war aber auf verschiedene, voneinander getrennte Gebiete und bestimmte Tiefen beschränkt.

\section{Introduction}

A Holocene coastal plain sequence is characterised by frequent lateral migration of coastal sedimentary environmental elements and their vertical sequence reflects the nature of coastal changes (KRAFT 1978). Moreover the development of the coastal plain through time is dominated by its subsoil. Only the knowledge of the complete vertical sequence and the interrelationship of the different depositional sedimentary environments in their areal distribution and through time can lead to a total understanding of the geological evolution of an area in study.

*) Address of the author: Dr. C. Baeteman, Geological Survey of Belgium, Jennerstraat 13, B - 1040 Brussel. 
As an example a small area from the western coastal plain of Belgium (fig. 1) is shown. It is characterized by a narrow zone of sand deposits occurring up to a great depth which extends rather far inland.

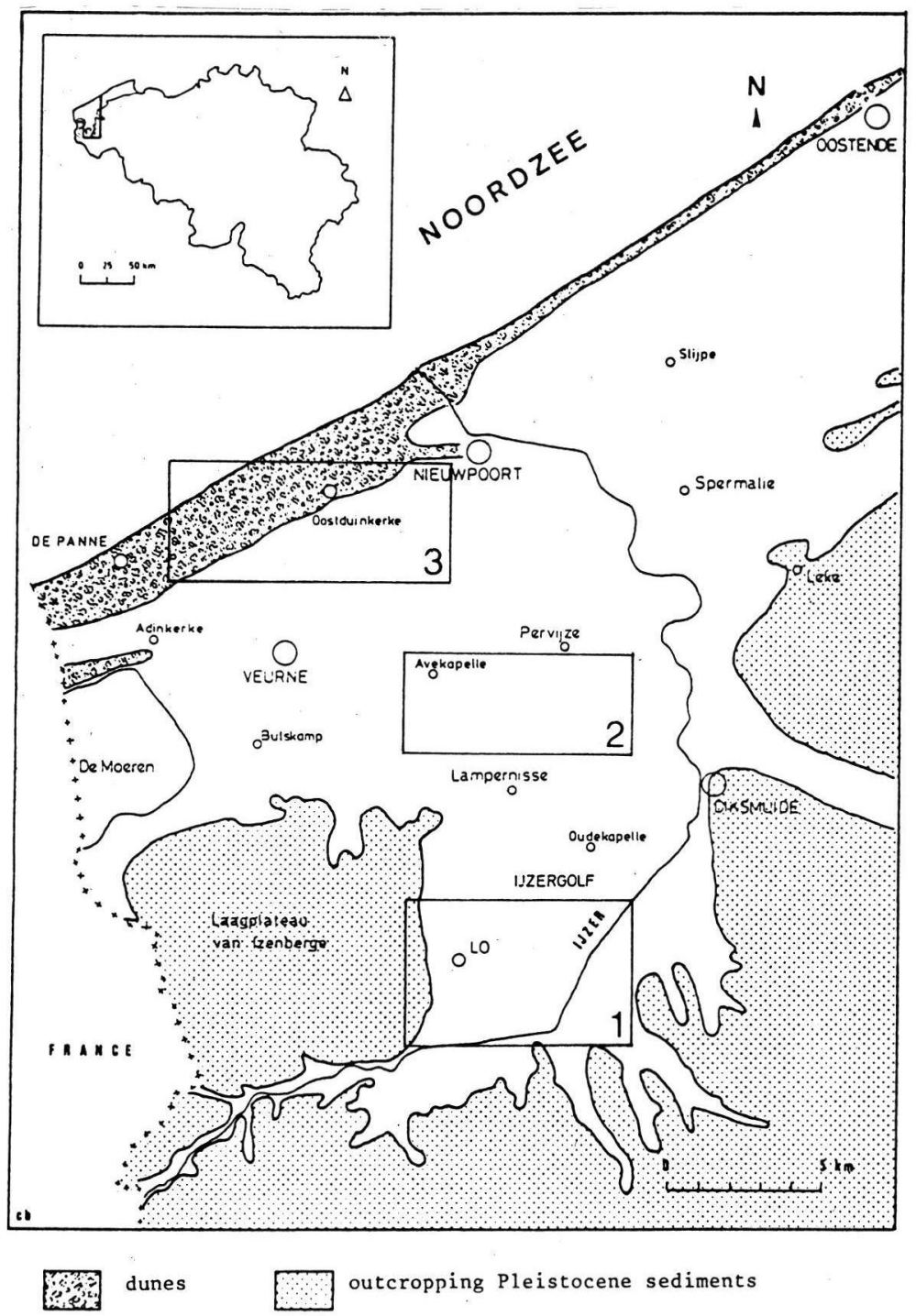

Fig. 1: Map of the western coastal plain of Belgium with location of panel diagrams. 


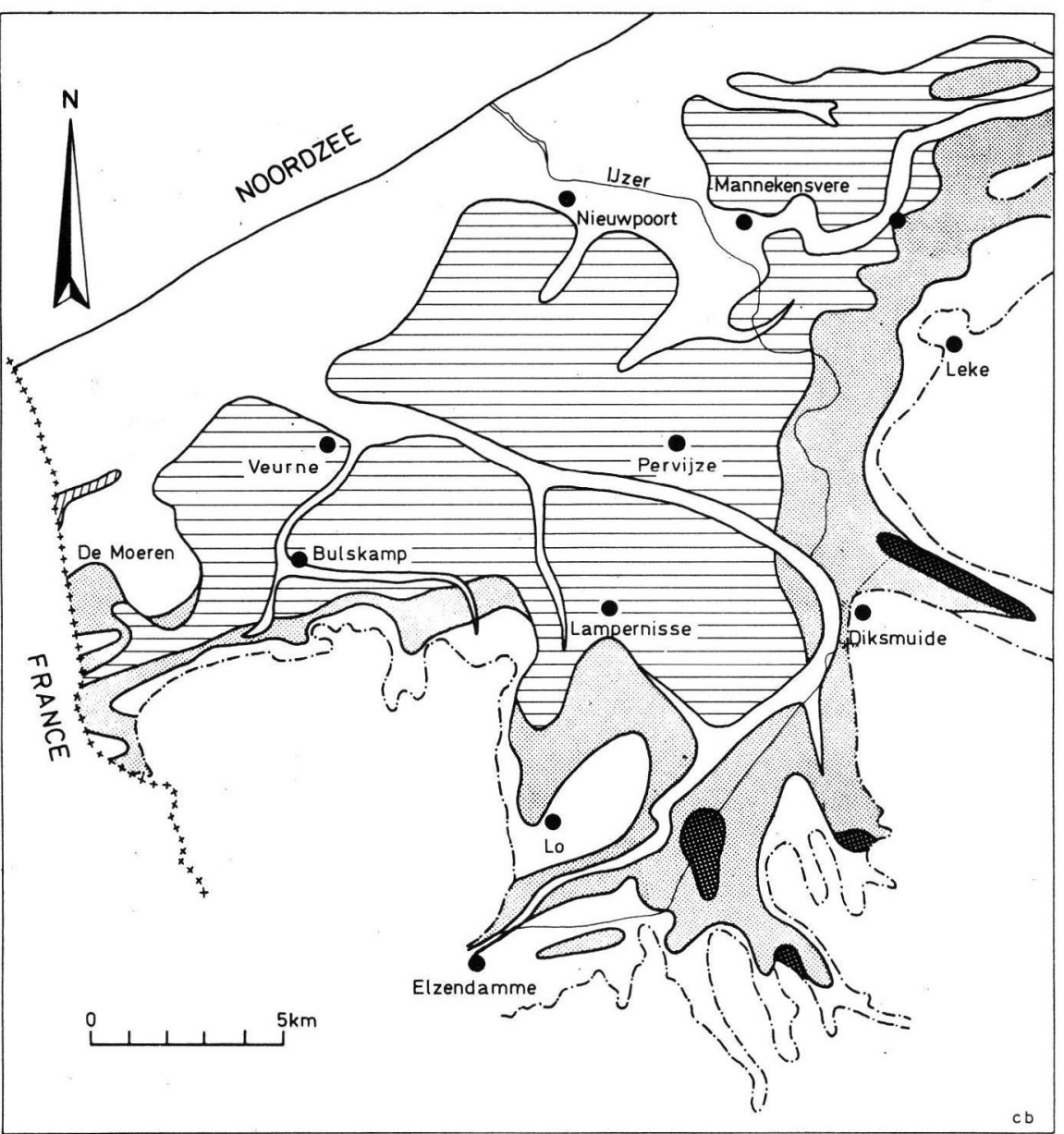

PRINCIPAL PROFILE TYPE MAP

XI - profile type

$Y$ - profile type

$\times 2$ - profile type

$Z$ - profile type

X 3 - profile type

Fig. 2: The large scale principal profile type map of the western coastal plain shows the three main different sedimentary successions. 


\section{The Geological Evolution of the Area during the Holocene}

\section{Principal profile type map}

The very general lithologic profile type map (fig. 2) (according to BARCKHAUSEN et al. 1977) indicates mainly 3 different kinds of sedimentary succession. The X-profile type represents a sedimentary sequence consisting of only clastic sediments. The presence of basal peat is shown by the $\mathrm{X}_{2}$-profile type. As up to now only few data are available for the deepest part along the actual shoreline the presence of basal peat is not indicated in the very seaward area. The $\mathrm{X}_{3}$-profile type occurring in a very restricted part in the west demonstrates the presence of an organic cover layer above an entire clastic sequence. The Y-profile type stands for a sedimentary sequence consisting of clastic sediments with intercalated peatlayers while in the Z-profile type sedentary organic deposits are dominant.

The area in study covers that nearly west-east extension of the X-profile type. The presence of the sand deposits used to be interpreted by the soilmapping as an erosive phenomenon whereby, during the post-Roman transgression, the peatlayer was entirely eroded by creeks and deposition of sand took place (TAVERNIER 1947, MOORMANN 1951). Indeed this rather simple interpretation was used to explain the genesis of all areas in the coastal plain where only sand was occurring without any peatlayer.

However it is impossible to understand the genesis of an area in a coastal plain without knowing the nature of the record underneath, its interrelationship with the adjacent zones and after all the morphology of its subsoil.

\section{Morphology of the subsoil}

The subsoil of the Holocene deposits in the studied area consists of Weichselian coversands underlain by marine deposits of most probably Eemian age and in some cases, where the Pleistocene sediments are entirely eroded, of Eocene (Ypresian) deposits.

The morphology of the subsoil (fig. 3) demonstrates an important depression nearly perpendicular to the present shoreline and extending rather far landward. The question arises whether or not this depression is due to erosion during the Holocene.

\section{The Holocene sequence in the depression}

In the southern most part of the plain, where the depression still is expressed, the Pleistocene deposits are directly covered by a well developed peatlayer overlain by tidal flat sediments (fig. 4). The presence of the basal peat, the forerunner of a rising sealevel, demonstrates that the depression already existed before the rising Holocene sealevel influenced that particular area.

In the deeper part of the depression, slightly more seaward, a more complex Holocene sequence is occurring. As demonstrated by the boring of Oostkerke (fig. 5) the 


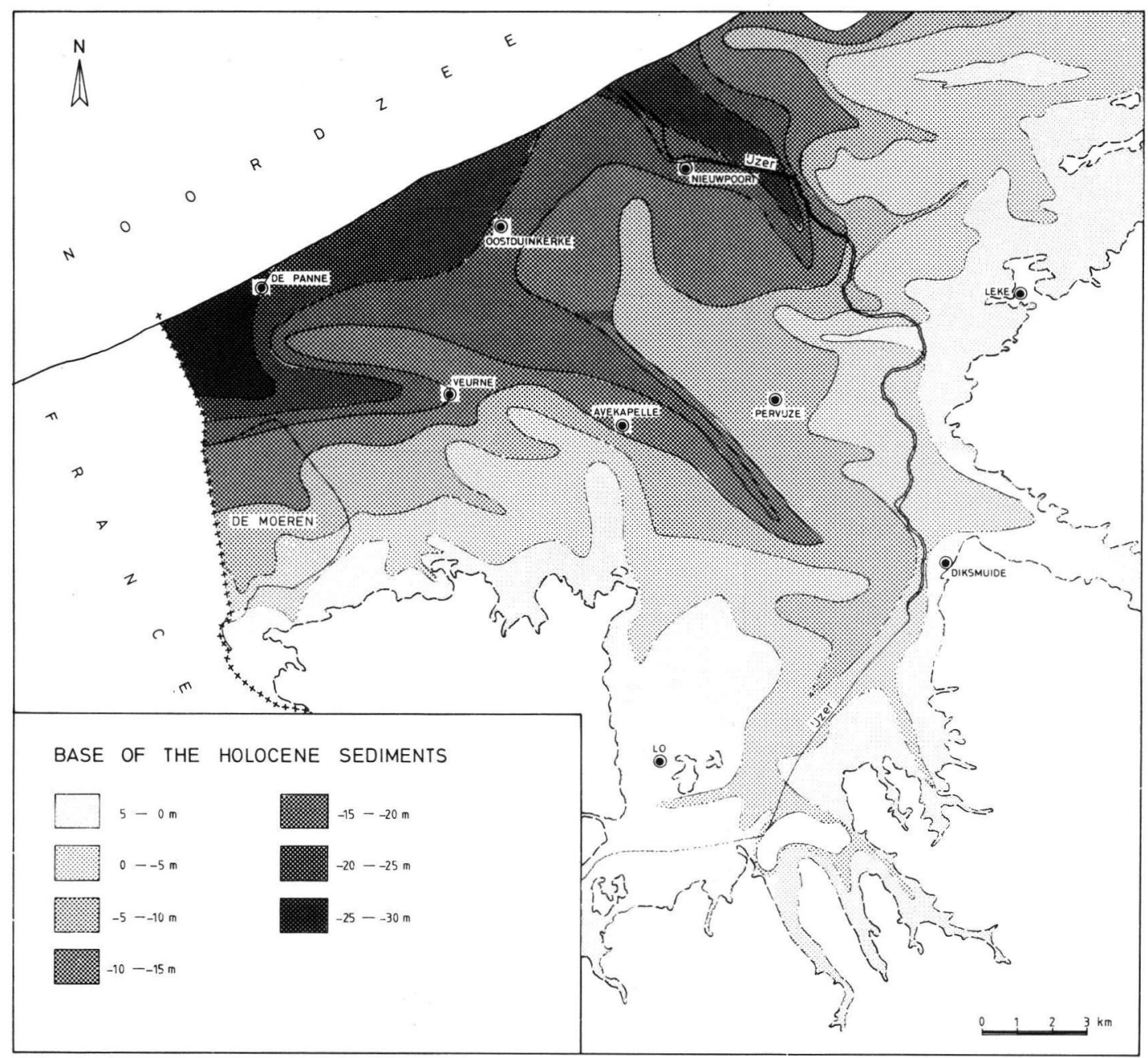

Fig. 3: Morphology of the subsoil.

vertical Holocene sequence includes from bottom to top a basal peat which gradually evolves to mud from the lagoonal facies (sensu STREIF 1972) overlain by mud from the mixed and mud flat shifting into fine silty sand from the sand flat environment.

These vertical gradual changes of sedimentary environments from the basal peat up to the sandflat demonstrates a gradual increase of the influence of the Holocene sealevel rise in that particular area without any aggressive erosive evidence. They prove that the depression is not the result of erosion during the Holocene, but on the contrary it belongs to the areas which were first of all occupied by the invading sea and where a tidal flat and more particular a sand flat environment came into being in which tidal channels developed. 


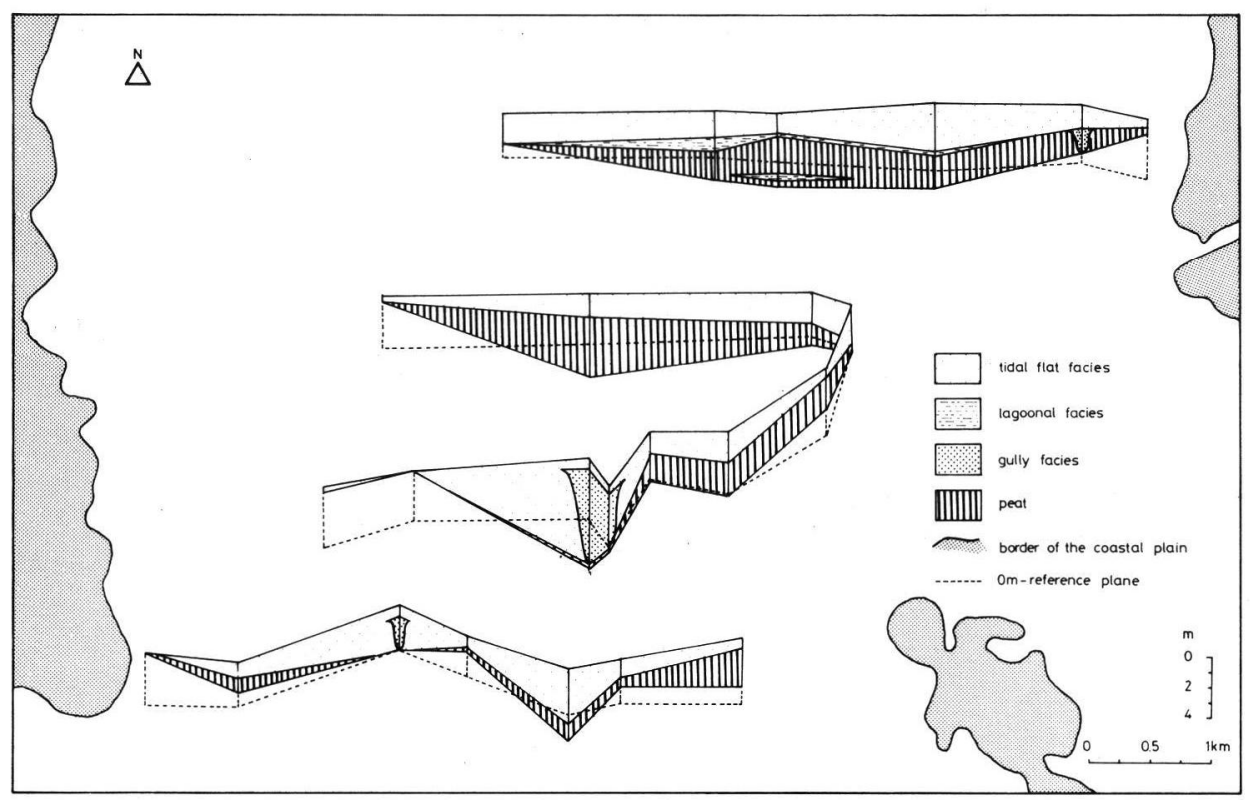

Fig. 4: Panel diagram of the southern most part of the coastal plain showing the entire Holocene sequence up to the Pleistocene deposits.

Location: see fig. 1, diagram 1.

As from about 7000 Yr B.P. a decrease of direct marine influence resulted in a gradual change to mud flat which in turn evolved to a peat growth. In the same period the basal peat started to develop on a slightly higher parts of the depression (fig. 6). After about 6700 Yr B.P. the marine influence suddenly became more significant as a tidal channel could develop in the central part of the depression. At the same time the tidal flat environment was subject to a greater extension and caused the end of the basal peat growth on the slopes of the depression. The presence of the tidal flat and more particularly the mixed flat in the outer part of the depression is directly related to the tidal channel which is responsable for the fact that the direct marine influence is brought in so that a broad tidal flat environment can come into existence as far landward. The sedimentary sequence which normally is expected in the more landward areas consists of a succession of only lagoonal mud with intercalated peatlayers.

The tidal flat environment lasted until about $5000 \mathrm{Yr}$ B.P. until when a peat growth started to develop. This peatlayer represents the uppermost one and was of great importance as it covered nearly the entire coastal plain. Toward the top the peat gradually evolves to an organic mud covered by sediments of the tidal flat. A strong and quick rise of the groundwater-level under predominantly oligothrophic conditions is responsable for the end of the peat growth at about $3000-3300 \mathrm{Yr} \mathrm{B}$. P. (BAETEMAN 1981) and in some cases, more landward, at about 2000 Yr B. P. (BaEteman \& VeRBRUGGen 1979). The landscape was transformed into a broad shallow lagoonal environment and only later on it developed into a mud flat and salt marsh. 


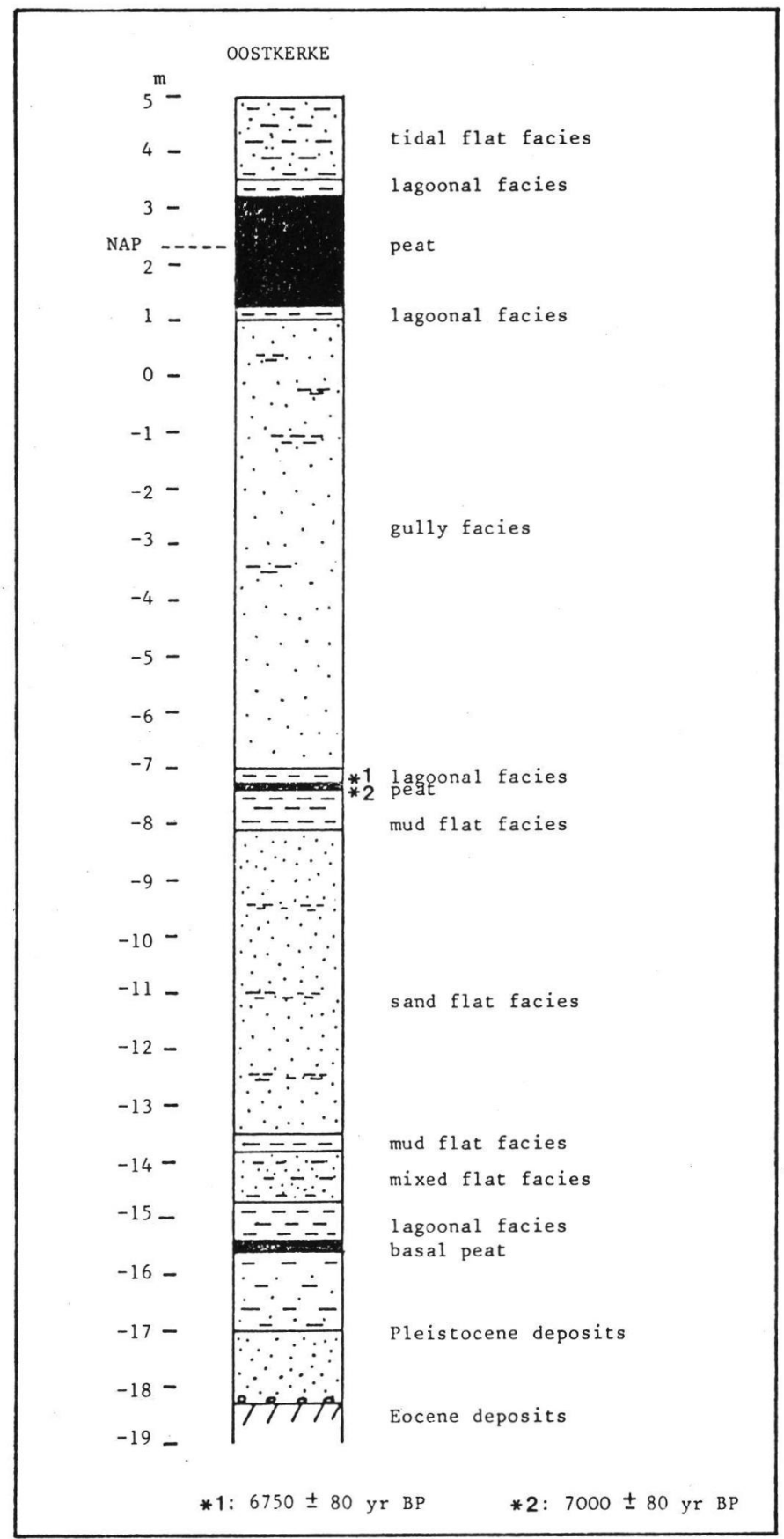

Fig. 5: Boring at Oostkerke demonstrating the gradual changes of sedimentary environments in the Holocene sequence. 


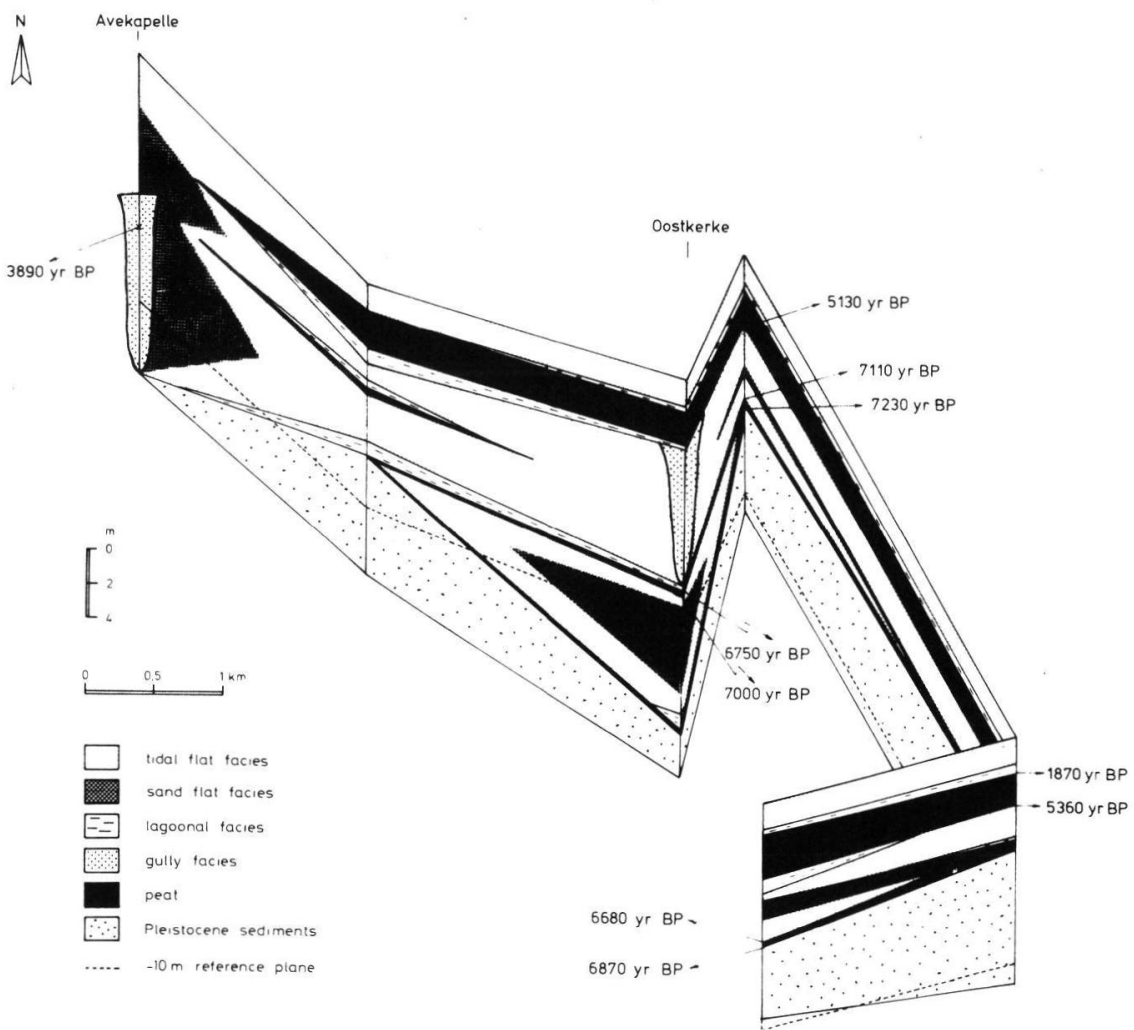

Fig. 6: Panel diagram of the depression showing the entire Quaternary sequence up to the Eocene deposits. The diagram illustrates the relationship of the central part of the depression with its adjacent zone (in the east) and shows the well expressed relief of the Pleistocene subsoil. Location: see fig. 1, diagram 2.

In the slightly seaward part of the depression however, the Holocene sequence shows a quite different sedimentary succession as demonstrated by the boring of Avekapelle (fig. 6).

The Eocene subsoil is directly covered by sand flat and tidal channel deposits. The basal peat and even the whole of the Pleistocene sediments are lacking. The gully facies is rather heterogeneous. It consists of sand and silt with as coarse elements mud pebbles, shelldebris, big peat fragments and also whole blocks of clay on to a thickness of $0.5 \mathrm{~m}$ in which in situ peat layers can frequently be found. This demonstrates that the eroded deposits were not transported over a long distance. Some of the peat blocks from the gully facies were dated at different locations. Their 14-C age $(2680 \pm 60,2870 \pm 60$, $3890 \pm 70$ Yr B. P.) yields that they originate from the uppermost peat layer. However it is remarkable that the coarse material, and in particular the big peat blocks, are all concentrated at a depth between $-5 \mathrm{~m}$ and $-7 \mathrm{~m}$ and do not occur in the lower most part of the gully situated at about $-15 \mathrm{~m}$. 
This typical facies of the upper part of the gully deposits give evidence of an erosive phase from one of the post - Roman transgressions but whereby most probably the base of erosion was situated not deeper than $-7 \mathrm{~m}$. At the very seaward zone of the depression however, the lower most part of the gully shows a particular facies. It is especially characterized by plenty of reworked Pleistocene deposits, clay pebbles from the Eocene deposits, cobbles, many shells and humic sand and sandy peat fragments originating from the basal peat.

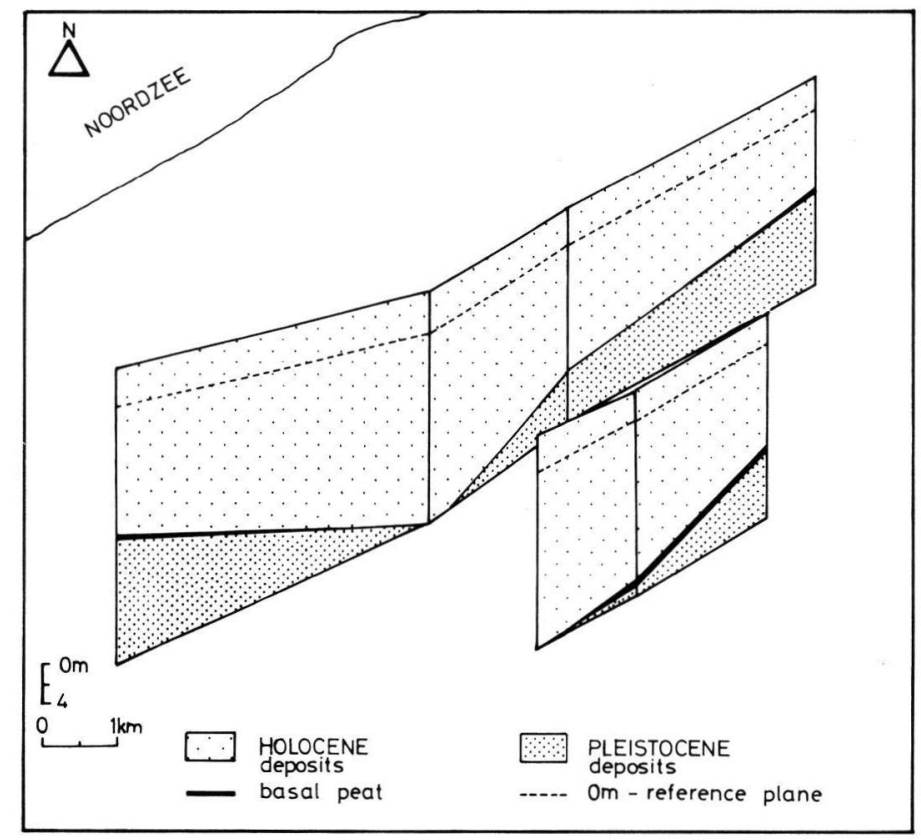

Fig. 7: Panel diagram of the depression in the seaward area illustrating the erosion of the Pleistocene sediments up to the Eocene deposits. Location: see fig. 1, diagram 3.

A series of borings across the depression (fig. 7) shows that the Pleistocene deposits are lacking completely in the central zone of it while on its slopes the basal peat and only a small part of the Pleistocene sediments were eroded. The evidence that a peat or a soil was present at or in the top of the Pleistocene deposits is indeed still distinctly visible. Farther from the central part the basal peat is present but at a considerable depth of $-17 \mathrm{~m}$.

Also in the very seaward area the depression existed before the Holocene sea-level rise influenced the area, but a considerable erosion, mainly in the central part, occurred and this most probably as from the very beginning of the Holocene. 


\section{Final Considerations}

The study of sedimentary environments through space and time obviously can lead to a better understanding of changes in coastal configuration. Although their facies do not always represent an important thickness in the vertical sequence, they belong to the important basic elements necessary to delineate the geological evolution.

A narrow sandy area extending far inland which used to be interpreted as the result of one single deep erosive action of post-Roman time turned out to bear a much more complex history.

An existing depression in the Pleistocene deposits was one of the areas which in the Holocene were first of all invaded by the sea. There a tidal flat came into being and the tidal channels show the evidence of several phases of development whereby erosive actions were restricted to different places and depths.

\section{References}

Bateman, C. (1981): De Holocene ontwikkeling van de Westelijke kustvlakte (België). - Proefschrift, 297 p.; Brussel.

- \& Verbruggen, C. (1979): A new approach of the so-called surface peat in the western coastal plain of Belgium. - Prof. Paper, 11, 167: 21 p.; Brussel.

Barckhausen, J., Preuss, H. \& STreif, H. (1977): Ein lithologisches Ordnungsprinzip für das Küstenholozän und seine Darstellung in Form von Profiltypen. - Geol. Jb., A 44: 45-74; Hannover.

KRAFT, J. C. (1978): Coastal Stratigraphic Sequences - In Davis, R. A. (ed.), 1978: Coastal Sedimentary Environments. - 361-383. New York, Heidelberg, Berlin (Springer).

Moormann, F. R. (1951): Verklarende tekst bij het kaartblad Lampernisse 51 W. - Bodemkaart van België: $55 \mathrm{p}$.

StREIF, H. (1972): The Results of Stratigraphical and Facial Investigations in the Coastal Holocene of Wolzeten/Ostfriesland, Germany. - Geologiska Föreningen i Stockholm Förhandlingar. 94 (2): 281-299; Stockholm.

TAVERNIER, R. (1947): L'évolution de la plaine maritime belge. - Bull. Soc. belge Géol. 56: 332-343; Brussel.

Manuscript accepted on 10.10. 1984 